\title{
Kinerja Pegawai dalam Pelayanan Administrasi di Kantor Kecamatan Boliyohuto Kabupaten Gorontalo
}

\author{
${ }^{1}$ Umar Sako Baderan, ${ }^{2}$ Yespin Ingo \\ ${ }^{1}$ Program Studi Administrasi Publik Universitas Muhammadiyah Gorontalo \\ ${ }^{2}$ Program Studi Administrasi Publik Universitas Muhammadiyah Gorontalo \\ Gorontalo,Indonesia \\ Email : usbaderan@gmail.com
}

\begin{abstract}
The purpose of this study is to find out how the performance of employees in performing administrative services in Boliyohuto District Office. The research method used is a quantitative approach with correlation method. The result of the writer's observation on the performance of the employees in the administrative service at Boliyohuto Sub-District Office still needs some improvement. Based on the results of research that influence the performance of employees to administrative services in District Boliyohuto Gorontalo Regency, according to the results of testing the hypothesis that the price t arithmetic> of the price register. The closeness of the influence of the performance of employees to the administrative service is shown through calculation of determination that is approximately $40 \%$ variation that occurs in the scores of administrative services explained through the variation of employee performance in the district office Boliyohuto Gorontalo District. Improvement of administrative services has a significant (significant) relationship with employee performance through the relationship pattern shown by regression equation $=15+0.95 X$ which is very meaningful. In conclusion that every change of one unit on variable $X$ is the employee performance followed by the average change of 0.81 units on variableYyaitu administrative services in the district office Boliyohuto Gorontalo District.
\end{abstract}

Keywords: Performance; Staff Administration Services

\begin{abstract}
Abstrak
Tujuan dalam penelitian ini ialah untuk mengetahui bagaimana kinerja pegawai dalam melakukan pelayanan administrasi di Kantor Kecamatan Boliyohuto. Metode penelitian yang digunakan ialah dengan pendekatan kuantitatif dengan metode korelasi. Hasil pengamatan penulis pada kinerja pegawai dalam pelayanan administrasi di Kantor Camat Boliyohuto masih memerlukan beberapa pembenahan. Berdasarkan hasil penelitian bahwa pengaruh kinerja pegawai terhadap pelayanan administrasi di Kecamatan Boliyohuto Kabupaten Gorontalo, sesuai hasil pengujian hipotesis yaitu harga $t$ hitung $>$ dari harga tdaftar. Keeratan pengaruh kinerja pegawai terhadap pelayanan administrasi ditunjukkan melalui perhitungan determinasi yaitu kurang lebih $40 \%$ variasi yang terjadi pada skor pelayanan administrasi terjelaskan melalui variasi kinerja pegawai di kantor Kecamatan Boliyohuto Kabupaten Gorontalo. Peningkatan pelayanan administrasi memiliki hubungan yang signifikan (berarti) dengan kinerja pegawai dengan melalui pola hubungan yang ditunjukkan oleh persamaan regresi $=15+0,95 X$ yang sangat berarti. Kesimpulannya bahwa setiap terjadi perubahan satu unit pada variabel $X$ yaitu kinerja pegawai diikuti oleh perubahan rata - rata sebesar 0,81 unit pada variabelYyaitu pelayanan administrasi di di kantor Kecamatan Boliyohuto Kabupaten Gorontalo.
\end{abstract}

Kata Kunci : Kinerja; Pegawai;Pelayanan Administrasi 


\section{PENDAHULUAN}

Kinerja merupakan produk dari melakukan segala sesuatu yang berhubungan dengan suatu pekerjaan, jabatan, atau peranan dalam organisasi dengan penuh rasa tanggung jawab, dedikasi dan loyalitas yang maksimum.kerja yang dimaksudkan dalam penelitian ini yaitu segala daya upaya yang dilakukan oleh pegawai dalam memberikan pelayanan administrasi terhadap warga masyarakat. Kinerja yang diharapkan ini tercermin pada tiga aspek yakni aspek kognitif yaitu pemahaman pegawai tentang sistem pelayanan administrasi kepada masyarakat. Aspek afektif yaitu kinerja aparat pegawai dalam memberikan pelayanan adalah upaya yang dilakukan oleh pegawai untuk menerima dan menciptakan hubungan interpresonal yang harmonis dengan masyarakat. Aspek kinerja adalah segala upaya yang dilakukan pegawai dalam menggunakan fisik dalam bertindak sehingga dapat memberikan pelayanan yang terbaik kepada masyarakat.

Pegawai yang berhasil dengan baik dalam melayani berbagai kepentingan administrasi bagi warga masyarakat, apabila mampu memahami dan melaksanakan peran sebagai orang yang diberi tanggung jawab untuk mengelola administrasi pemerintahan di tingkat kecamatan. Selanjutnya bahwa keberhasilan pegawai juga sangat bergantung pada pimpinannya, dalam hal ini pimpinan kecamatan. Camat merupakan simbol kepemim-pinan yang ada pada tingkat Kecamatan, dan sudah pasti Camat yang baik adalah yang mampu menjadi pengayom bagi seluruh yang dipimpinnya, baik itu yang ada di Kantor Camat maupun yang ada di Lingkungan Kecamatan yaitu masyarakatnya, (Akbar,2015:158)
Tugas seorang pegawai sebagai aparatur negara merupakan penentu dalam menentukan, mengembangkan dan memajukan organisasi pemerintahan. Rumusan ini mengindikasikan betapa penting kinerja pegawai dalam menyelenggarakan sistem pemerintahan guna mengoptimalkan pelayanan kepada warga masyarakat. Peran sentral pegawai dalam melayani kepentingan administrasi masyarakat ditingkat kecamatan diharapkan sebagai kekuatan yang dapat menggerakan roda kehidupan masyarakat. Karena itu seorang pegawai sangat diharapkan untuk memahami dengan jelas, tentang tugas yang menjadi tanggung jawabnya, memiliki kepedulian terhadap masyarakat demi mengoptimalkan pelayanan publik.

Selanjutnya kualitas pelayanan administrasi kepada masyarakat merupakan tingkat ketercapaian dari tujuan dalam organisasi yang menyangkut produk maupun jasa primer yang dihasilkan. Untuk mendukung kedua hal ini seorang pegawai harus memiliki pengetahuan dan wawasan tentang pengelolaan administrasi sebagai faktor utama dari keberhasilan pelayanan administratif dan harus menjadi pegangan utama bagi pegawai dalam melaksanakan tugasnya.

Ditinjau dari aspek afektif menunjukkan bahwa suasana hubungan kerja sama antara sesama pegawai penciptaan suasana keakraban dan persahabatan dengan masyarakat belum tercermin dengan baik. Demikian pula respon dan sikap saling menghargai terhadap masyarakat masih belum nampak dalam memberikan pelayanan.

Kinerja pegawai di Kantor Camat Boliyohuto masih rendah,hal ini dipengaruhi oleh beberapa faktor seperti 
penguasaan terhadap penggunaan alat yang digunakan untuk membantu kelancaran pelaksanaan tugas yang nampak masih kurang, beban tugas yang tidak merata bagi setiap pegawai. Keadaan ini berakibat buruk terhadap tugas dan tanggung jawab pegawai baik sebagai aparat aparatur negara dan pelayanan bagi warga masyarakat, administrator dan kurang berjalan dengan lancar. Kinerja pegawai dalam mengatasi dan memecahkan segala permasalahan yang dihadapi dalam melaksanakan tugas pokok belum profesional, sehingga timbul keluhan dari beberapa masyarakat karena permintaan mereka yang sering tidak diselesaikan tepat waktu.

Kondisi lain menunjukkan bahwakinerja pegawai dalam memberikan pelayanan di kantor Camat Boliyohuto, masih memerlukan beberapa pembenahan. Berdasarkan hasil observasi menunjukkan bahwa ada sebagian pegawai belum memiliki kinerja yang memadai dalam melakukan tugas administrasi. Hal ini tercermin pengetahuan pegawai dalam memahami prosedur dan jenis pelayanan yang masih kurang. Misalnya dalam menyusun konsep surat yang selalu menunggu atasan. Kondisi ini mengakibatkan terlambatnya pemberian pelayanan kepada masyarakat.

\section{METODE PENELITIAN}

Penelitian ini dilaksanakan di Kantor Kecamatan Boliyohuto Kabupaten Gorontalo. Alasan pemilihan lokasi penelitian adalah karena pemerintah Kecamatan yang memberikan pelayanan administarsi, sehingga hasil penelitian diharapkan memberikan data yang cukup memadai dalam memberikan kesimpulan penelitian. Waktu yang diperikirakan dalam pelaksanaan penelitian ini adalah selama 3 bulan.

Dalam penelitian ini menggunakan metode korelasional, yang bertujuan (1) untuk mengetahui hubungan kinerja pegawai terhadap prosedur pelayanan administrasi di Kecamatan Boliyohuto Kabupaten Gorontalo, (2) untuk mengetahui hubungan kinerja pegawai terhadap kemampuan memberikan pelayanan administrasi di kantor Kecamatan Boliyohuto Kabupaten Gorontalo.

Penelitian ini terdiritas dua variabel yaitu kinerja pegawai adalah variabel $\mathrm{X}$ dan pelayanan administrasi adalah variabel Y. Adapun definisi konseptual dan operasional kedua variabel ini diuraikan sebagai berikut.

\section{1,1.1. Variabel terikat (X) adalah kinerja} pegawai

2. Variabel bebas (Y) adalah pelayanan administrasi

Populasi penelitian ini adalah keseluruhan pegawai pada Kantor Camat Boliyohuto dan seluruh Kepala Desa di Kecamatan Boliyohuto yang berjumlah 51 orang. Penentuan ukuran sampel menggunakan sampel total yaitu jumlah anggota sampel sama dengan anggota populasi, sehingga besarnya sampel yang digunakan dalam penelitian ini sebesar anggota populasi yaitu 51 orang. Penentuan anggota sampel dalam penelitian ini didukung oleh penegasan Arikunto (1999:120) yaitu "Untuk ancerancer bila jumlah populasi kurang dari 100, maka dapat diambil semuanya untuk dijadikan sampel dan penelitian disebut dengan penelitian populasi, sedangkan bila jumlah populasi lebih dari 100, dapat diambil antara $10-15 \%$, atau $15-20 \%$ atau lebih dari itu disesuaikan dengan kemampuan peneliti dari segi waktu, tenaga dan biaya". 
Selanjutnya kriteria Pengujian : $\mathrm{r}_{\mathrm{xy}}$ hitung > $r$ daftar tabel dengan jumlah sampel pada taraf nyata $\alpha=0,05$ maka angket benarbenar memiliki validitas,untuk harga selain angket ditolak validitasnya. Rumus yang digunakan dalam pengujian reliabilitas angket ini adalah rumus alpha Croubach yaitu :

$$
r_{11}=\left(\frac{k}{k-1}\right)\left(1-\frac{\Sigma \sigma_{1}^{2}}{\sigma_{1}^{2}}\right)
$$

Keterangan :

$$
\begin{array}{ll}
\mathrm{r}_{11} & =\text { realibitas instrumen } \\
\mathrm{k} & =\text { banyaknya butir soal } \\
\Sigma \sigma_{1}^{2} & =\text { jumlah varians tiap item } \\
\sigma_{1}^{2} & =\text { varians total }
\end{array}
$$

Teknik analisa data yang digunakan adalah analisa korelasi regresi. Dalam pengujian hipotesis yang telah dirumuskan, analisis data hasil penelitian adalah dengan cara statistik. Guna menentukan harga $t$ statistik ini, maka yang dapat dilakukan adalah uji persyaratan analisis. Penggunaan statistik uji ini dari metodologinya haruslah memenuhi asumsi populasinya mempunyai fungsi distribusi normal.

Untuk memenuhi persyaratan tersebut, sebelum masuk pada pengujian hipotesis penelitian, dipandang perlu mengadakan pengolahan data yang dititikberatkan pada pengujian normalitas data.

Pengujian normalitas data dilakukan dengan tujuan untuk mengetahui apakah data dalam penelitian ini berdistribusi normal atau berasal dari populasi penelitian yang berdistribusi normal. Pasangan hipotesis yang diuji adalah :

$$
\begin{array}{lll}
\mathrm{H}_{\mathrm{o}} & : & \text { Populasi berdistribusi normal } \\
\mathrm{H}_{1} & : & \begin{array}{l}
\text { Populasi tidak berdistribusi } \\
\text { normal }
\end{array}
\end{array}
$$

Pengujian

normalitas

data menggunakan uji Liliefors, dengan kriteria pengujian. Data berdistribusi normal apabila Lo hitung $<$ Lo daftar pada taraf nyata $\alpha=0,01$. Untuk pengujian normalitas ditempuh langkahlangkah sebagai berikut :

1. Pengamatan $x_{1}, x_{2}, x_{n}$ dijadikanngka baku $\mathrm{z}_{1}, \mathrm{z}_{2}$...dengan rumus :

$$
Z i=\frac{X i-\bar{X}}{S}
$$

dimana :

$\mathrm{Xi}=$ batas kelas

$$
\bar{X}=\text { rata-rata skor }
$$

$\mathrm{S}=$ simpangan baku dari sampel

2. Untuk tiap angka baku menggunakan daftar distibusi normal baku, kemudian menghitung peluang $\mathrm{F}_{(\mathrm{Zi})}=\left(\mathrm{P}_{(\mathrm{Z} \leq \mathrm{Zi})}\right)$

3. Mengitung proporsi $\mathrm{z}_{1}, \mathrm{z}_{2}, \ldots \mathrm{z}_{\mathrm{n}}$ yang lebih kecil atau sama dengan zi dan dinyatakan dengan $\mathrm{S}$ (zi) melalui rumus sebagai berikut :

$$
\mathrm{S}(\mathrm{zi})=\text { Banyaknya } \frac{Z_{1}, Z_{2}, \ldots . Z_{n}}{n}
$$

4. Menghitung $\mathrm{F}_{(\mathrm{zi})}-\mathrm{S}_{(\mathrm{zi})}$ dan tentukan harga mutlaknya.

5. Ambil harga yang paling besar dintara harga-harga mutlak selisih tersebut sebagai hasil atau harga $\mathrm{Lo}_{\text {hitung. }}$.

(Sudjana, 2006 : 267)

\section{HASIL DAN PEMBAHASAN}

Pada bagian akan disajikan hasil penelitian dan pembahasannya, yang meliputi (1) deskripsi data, (2) pengujian persyaratan analisis dan (3) pengujian hipotesis.

\section{Deskripsi Hasil Penelitian}

Sesuai data yang diperoleh maka secara umum pemaparan hasil pengelolaan 
data varibel X (kinerja pegawai) menunjukkan bahwa jumlah sampel sebanyak 51 responden, jumlah skor ideal sebesar 7140, jumlah skor capaian responden sebesar 4564 atau 63,92\% berkualitas cukup dan rata-rata skor capaian responden 89,49 .

\section{Pengujian persyaratan analisis}

1) Pengujian homogenitas

Berdasarkan hasil perhitungan dimana derajat kebebasan $\mathrm{dk}=19$ dan taraf nyata $\alpha$ $=0,01$ diperoleh harga $\chi^{2}=36,2$ dan harga $\chi_{\text {hitung sebesar } 17,09 \text { sehingga dapat }}^{2}$ disimpulkan bahwa $\chi^{2}{ }_{\text {hitung }}<\chi_{\text {tabel }}^{2}$ atau 17,09 ebih kecil dari 36,2 sehingga dapat disimpulkan bahwa varians populasi homogen.

2) Pengujian Normalitas Data

Data yang telah dijaring melalui angket untuk selanjutnya dianalisis secara kuantitatif melalui uji parametrik, dalam hal ini data yang terkumpul haruslah memenuhi asumsi normal. Sebaliknya jika data yang terkumpul tidak berdistribusi normal, maka digunakan uji statistik uji non parametrik. Untuk pengujian normalitas digunakan uji Lilliefors.

Berdasarkan data diperoleh harga Lo hitung lebih kecil dari harga Lo daftar atau $0,1822<0,1538$. Untuk variabel Y (pelayanan administrasi) sesuai hasil perhitungan harga Lo hitung lebih kecil dari harga Lo daftar atau $0,1822<0,0498$.

\section{Pengujian Hipotesis}

Sesuai hasil pengujian normalitas data menunjukkan bahwa data dalam penelitian ini memenuhi syarat untuk dilakukan pengujian hipotesis melalui statistik parametriks berupa analisis regresi dan korelasi sederhana dengan menempuh langkah-langkah sebagai berikut :

a. Menduga Persamaan Regresi Liniar Sederhana. Y dan X

Dalam menduga persamaan regerensi linier sederhana $\mathrm{Y}$ dan $\mathrm{X}$ dilanjutkan menghitung konstanta $a$ dan koefisien regresi $b$ dan hasil perhitungan pada lampiran 5 yaitu harag $\mathrm{a}=15$ dan harga $\mathrm{b}=0,95$, harga diperoleh persamaan regresi sederhana berbentuk $\hat{Y}=18+0,81 \mathrm{X}$. b. Uji linier dan Keberartian Persamaan Regresi

Hasil perhitungan ini menunjukkan bahwa harga $\mathrm{F}_{\text {hitung }}$ sebesar 0,18 harga ini bila dikonsultasikan dengan harga pada daftar distribusi untuk $F_{(0,99)(27,22)}=2,05$ ternyata $F$ hitung lebih kecil dari pada harga - harga $F_{\text {daftar}}$, sehingga dapat disimpulkan bahwa persamaan regresi $\hat{Y}=15+0,95 \mathrm{X}$. adalah berbentuk linear.

Uji Keberartian Regresi diperoleh diperoleh harga $F_{\text {hitung }}$ sebesar 77 sedangkan dari daftar distribusi untuk $\mathrm{F}_{(0,99)(1,49)}=7,44$. Bila harga ini dikonsultasikan ternyata $\mathrm{F}$ hitung lebih besar dari $\mathrm{F}$ daftar pada tabel, dengan demikian dapat disimpulkan bahwa persamaan regresi tersebut berarti (signifikan).

c. Mengitung Koefisien Korelasi

Berdasarkan data bahwa harga $r$ dihitung diperoleh sebesar $=0,611$ dan $\mathrm{r}^{2}=$ 0,373 atau $37 \%$. Hasil pengujian keberartian koefisien korelasi diperoleh harga yaitu dengan $\mathrm{dk}=49$ dan hasil perhitungan diperoleh harga $\mathrm{t}$ hitungsebesar 5,40 sedangkan daftar distribusi untuk $\mathrm{t}_{(0,975)(51)}=2,66$ dan ternyata harga $\mathrm{t}$ hitung $>$ dari harga $t$ daftar pada taraf nyata $\alpha=$ 0,01. Dengan demikian hasil $t_{\text {hitung }}$ menunjukkan berada di luar daerah penerimaan $\mathrm{H}_{0}$, berarti $\mathrm{H}_{0}$ di tolak dan dapat menerima $\mathrm{H}_{\mathrm{a}}$. Implikasinya terhadap hipotesis penelitian terdapat pengaruh yang signifikan antara kinerja pegawai terhadap pelayanan administrasi adalah terbukti dapat diterima dengan tingkat kepercayaan $99 \%$.

\section{Interpretasi hasil skor capaian Kinerja Pegawai. \\ Hasil pengolahan data menunjukkan} bahwa rata-rata jumlah skor untuk variabel $X$ sebagai variabel kinerja pegawai, sebesar 89,49 atau $63,92 \%$. Hasil bila dikaitkan dengan kriteria kualitas jawaban responden pada tabel 2 berada pada taraf kualitas yang tinggi. Kondisi ini menunjukkan bahwa kinerja pegawai dalam mengelola yang menunjukkan suatu kualitas cukup. Implikasi dari keadaan ini mengandung makna bahwa kinerja pegawai yang telah dilakukan selama ini memiliki kualitas yang cukup. 
Interpretasi hasil skor capaian Pelayanan Administrasi

Capaian responden pada hasil pengolahan data yaitu sebesar 99,49 atau sebesar $77,70 \%$ dan bila dikaitkan dengan kriteria kualitas jawaban responden ternyata berada pada kualitas yang tinggi. Kondisi ini memberikan gambaran bahwa pelayanan administrasi Kecamatan Boliyohuto Kabupaten Gorontalo termasuk pada kategori baik. Hasil dengan kualitas cukup ini sangatlah wajar karena secara riil menunjukkan bahwa pegawai yang bekerja pada kantor Kecamatan Boliyohuto adalah aparatur negara yang dituntut untuk memberikan pelayanan yang optimal terhadap masyarakat khususnya dalam pelayanan administrasi. Hal ini juga dikuatkan oleh keputusan MENPAN Nomor 63 Tahun 2003 yang menyatakan bahwa hakikat pelayanan publik adalah pemberian layanan prima kepada masyarakat yang merupakan perwujudan kewajiban aparatur pemerintah sebagai abdi masyarakat. Untuk dapat memberikan pelayanan yang memuaskan bagi pengguna jasa, penyelenggaraan pelayanan harus memenuhi asas-asas pelayanan sebagai berikut : transparansi, akuntabilitas, kondisional (efektifitas dan efisiensi), partisipatif, kesamaan hak serta keseimbangan hak dan kewajiban.

Jika sumber daya pegawai pada kantor Kecamatan Boliyohuto Kabupaten Gorontalo memadai, serta sarana dan prasarana yang mendukung pelaksanaan tugas pokok dan fungsi cukup memadai, yang kemudian ditunjang dengan alokasi dana yang memadai, maka kinerja guru akan semakin baik atau meningkat, dengan demikian pelaksanaan tugas pokok dan fungsi dapat dilaksanakan lebih optimal, akuntabilitas pelayanan akan lebih efektif, efisien dan lebih akomodatif, sehingga secara normatif dan fungsional akan terwujud profesionalisme dalam pelayanan.

Interpretasi pengaruh kinerja pegawai terhadap pelayanan administrasi

Sesuai hasil perhitungan diperoleh suatu pola hubungan fungsional antara variabel kinerja pegawai di Kecamatan Boliyohuto dalam bentuk persamaan regresi Linear sederhana yaitu : $\hat{Y}=15+0,95 \mathrm{X}$. Uji kelinieran dan keberartian persamaan regresi tersebut memberikan petunjuk bahwa terdapat hubungan fungsional yang signifikan (berarti) antara pelayanan administrasi. Penafsiran lebih dalam lagi mengandung makna bahwa rata-rata skor variabel pelayanan administrasi diperkirakan meningkat/menurun sebesar 0,611 untuk setiap peningkatan/penurunan variabel pelayanan administrasi sebesar satu unit.

Untuk harga antara variabel kinerja pegawai dengan pelayanan administrasi, dari hasil perhitungan diperoleh $r=0,40$ yang ternyata cukup berarti (signifikan), sehingga tidak dapat diabaikan. Harga ini bila ditafsirkan melalui koefisien derterminasi $(\mathrm{r}=$ 0,40 ) menunjukkan bahwa kurang lebih $0,40 \%$ variasi terjadi pada kinerja pegawai dengan skor pelayanan administrasi dengan persamaan regresi $\hat{Y}=15+0,95 \mathrm{X}$.

Pengaruh kinerja pegawai terhadap pelayanan administrasi ditunjukkan oleh koefisien determinasi tersebut merupakan suatu angka persentase yang cukup besar. Kondisi ini tidaklah mengherankan karena dalam kinerja pegawai, guna meningkatkan pelayanan administrasi memiliki keterkaitan antara keduanya.

Dalam pengujian $\mathrm{t}$ hitung sebesar 5,40 bila dikonsultasikan dari harga $\mathrm{t}$ daftar pada tabel distribusi untuk $\mathrm{t}_{(0,995)(80)}=2,66$. Oleh karena itu memnuhi kriteria yaitu $t_{\text {hitung lebih }}$ besar dibandingkan dengan $t$ daftar, maka berarti $\mathrm{t}_{\text {hitung }}$ telah berada di luar daerah penerimaan $\mathrm{H}_{\mathrm{o}}$, dan dapat menerima Ha. Kemudian implikasinya bahwa hipotesis alternatif yang berbunyi : terdapat pengaruh yang signifikan kinerja pegawai terhadap skor pelayanan administrasi di kantor Kecamatan Boliyohuto Kabupaten Gorontalo dapat diterima dengan tingkat kepercayaan 99\%.

Kinerja pegawai dalam memberikan pelayanan administrasi kepada masyarakat adalah gambaran dan karakteristik menyeluruh baik jasa maupun barang yang menunjukkan kinerja dalam memuaskan kebutuhan yang ditentukan atau yang tersirat. Selanjutnya 
kualitas pelayanan administrasi kepada masyarakat merupakan tingkat ketercapaian dari tujuan dalam organisasi yang menyangkut produk maupun jasa primer yang dihasilkan. Untuk mendukung kedua hal ini seorang pegawai harus memiliki pengetahuan dan wawasan tentang pengelolaan administrasi sebagai faktor utama dari keberhasilan pelayanan administratif dan harus menjadi pegangan utama bagi pegawai dalam melaksanakan tugasnya.

Berdasarkan berbagai uraian di atas maka untuk membuktikan kinerja pegawai di kantor Kecamatan Boliyohuto telah dilakukan penelitian secara sederhana dengan menggunakan instrumen skala sikap. Hasil pengolahan data dalam penelitian ini menunjukkan bahwa dominan kinerja pegawai terhadap pelayanan administrasi di kantor Kecamatan Boliyohuto Kabupaten Gorontalo adalah kategori bersikap positif dengan kualitas yang cukup. Kondisi ini menggambarkan bahwa pelayanan administrasi di kantor Kecamatan Boliyohuto mendapat mendapat persepsi baik.

\section{PENUTUP}

Kesimpulan :

1. Hasil pengolahan data menunjukan bahwa variabel kinerja pegawai (X) setelah dilakukan penyekoran diperoleh jumlah skor capaian responden sebesar 4564 atau 63,92\% dengan kualitas yang cukup dari skor ideal yang diharapkan. Kemudian kecenderungan secara keseluruhan berada dibawah dan di atas interval rata-rata yaitu masingmasing sebesar 25 atau $47 \%$.

2. Hasil pengolahan data menunjukkan bahwa skor capaian tentang pelayanan administrasi (Y) di kantor Kecamatan Boliyohuto diperoleh sebesar 5074 atau $77,77 \%$ dari skor ideal yang diharapkan, rata-rata sebesar 99,49 dengan kualitas cukup, dan kecenderungan data dibawah kelas interval rata-rata memiliki frekuensi mutlak sebesar 24 atau $46 \%$.
3. Pengaruh kinerja pegawai terhadap pelayanan administrasi di Kecamatan Boliyohuto Kabupaten Gorontalo, sesuai hasil pengujian hipotesis yaitu harga $\mathrm{t}$ hitung $>$ dari harga $t_{\text {daftar }}$. Keeratan pengaruh kinerja pegawai terhadap pelayanan administrasi ditunjukkan melalui perhitungan determinasi yaitu kurang lebih $40 \%$ variasi yang terjadi pada skor pelayanan administrasi terjelaskan melalui variasi kinerja pegawai di kantor Kecamatan Boliyohuto Kabupaten Gorontalo. Peningkatan pelayanan administrasi memiliki hubungan yang signifikan (berarti) dengan kinerja pegawai dengan melalui pola hubungan yang ditunjukkan oleh persamaan regresi $\hat{Y}=$ $15+\quad 0,95 \mathrm{X}$ yang sangat berarti. Kesimpulannya bahwa setiap terjadi perubahan satu unit pada variabel $X$ yaitu kinerja pegawai diikuti oleh perubahan rata - rata sebesar 0,81 unit pada variabelYyaitu pelayanan administrasi di di kantor Kecamatan Boliyohuto Kabupaten Gorontalo.

\section{Saran}

Berdasarkan kesimpulan di atas penulis menyampaikan beberapa saran :

1. Bagi pemerintah karena skor variabel kinerja pegawai merupakan salah satu faktor penentu keberhasilan dalam pelayanan kepada masyarakat, untuk memperhatikan kondisi ini berupa sistem pelayanan administrasi lebih cepat, tepat dan tidak berbelit-belit.

2. Hendaknya pelayanan administrasi di kantor Kecamatan Boliyohuto Kabupaten Gorontalo ini dapat lebih ditingkatkan untuk masa yang akan datang, karena memberikan manfaat yang bermakna bagi masyarakat, hal ini terlihat dari temuan penelitian bahwa mereka memiliki sikap yang cukup positif terhadap kinerja pegawai. 
3. Perlu adanya penelitian lanjutan terkait dengan penelitian ini agar lebih mendapatkan formulasi yang tepat dalam upaya meningkatkan kualitas pelayanan administrasi secara bertahap dapat dicapai.

\section{DAFTAR PUSTAKA}

Akbar, M. F. (2016). Analisis Peran Kepemimpinan Camat Di Kantor Kecamatan Bongomeme Kabupaten Gorontalo. JAKPP: Jurnal Analisis Kebijakan \& Pelayanan Publik, 1(2), 158-168.

Arikunto, Suharsimi.2001. Penelitian Suatu Pendekatan Praktek. Jakarta : Rineka Cipta.

Arsyad Azhar.2002. Pokok-Pokok Manajemen. Pengetahuan Praktis bagi Pimpinan dan Eksekutif. Makasar: Pustaka Pelajar.

Hamid, Abdul, 2003. Pedoman Pengembangan Administrasi dan Supervisi Pemerintahan. Jakarta: Depag RI.

Hanif Nurholis dkk. 2004. Administrasi Pemerintahan Kecamatan, Jakarta; penerbit Univeristas Terbuka.

Lazaruth Soewadji, 2000. Pegawai dan Tanggung Jawabnya, Jogyakarta : Kanisius.

Oteng Sutisna, 2000. Administrasi Pemerintahan, Dasar Teoretis untuk Praktek Profesional, Bandung: Angkasa.

Ridwan, 2004. Metode dan Tehnik Menyusun Tesis .Bandung: Alfabeta

Rivai Veitzhal, 2003. Kepemimpinan dan Perilaku Organisasi. Jakarta : Raja Grafindo Persada.
Soeprihanto, Jhon, 2000. Penilaian Kinerja dan Pengembangan Karyawan, Edisi pertama, Yogyakarta. : BPFE

Tika, P. 2006. Budaya Organisasi Dan Peningkatan Kinerja Perusahaan. Jakarta: PT Bumi Aksara. 